\title{
Neoproterozoic Paleoclimate in South China: perspectives on chemical weathering processes
}

LIANG QI ${ }^{1}$, PETER A. CAWOOD ${ }^{2}$, JiANGHAI YANG ${ }^{1}$, YAJUN $\mathrm{XU}^{1 *}$ AND YUANSHENG DU ${ }^{1}$

${ }^{1}$ School of Earth Sciences, China University of Geosciences, Wuhan, 430074, China

${ }^{2}$ School of Earth, Atmosphere \& Environment, Monash University, Melbourne, VIC 3800, Australia

Sediment generation from source-to-sink process involves primary mineral decomposition and mobile element release, which is sensitive to climate and tectonic processes. Based on modern regolith studies, various chemical weathering indices have been developed to estimate the intensity of rock chemical weathering with related to changing climatic conditions, and the relationship between the paleosurface temperatures and intensity of rock chemical weathering have been outlined by empirical climate transfer functions $[1,2,3]$. We apply the function to the Neoproterozoic suites constrain the mean annual temperature difference between glacial and interglacial periods in South China and Oman.

Covariant change of chemical weathering trends in South China and Oman reflects several Neoproterozoic contemporaneous climate cooling events and correlate with the Sturtian, Marinoan and Gaskiers glaciations. The estimated temperature differential between Cryogenian glaciation and interglaciation can reach $20^{\circ} \mathrm{C}$ at around 30 degrees paleolatitude, and $12^{\circ} \mathrm{C}$ temperature difference between the Ediacaran glaciation and interglaciation near the equator.

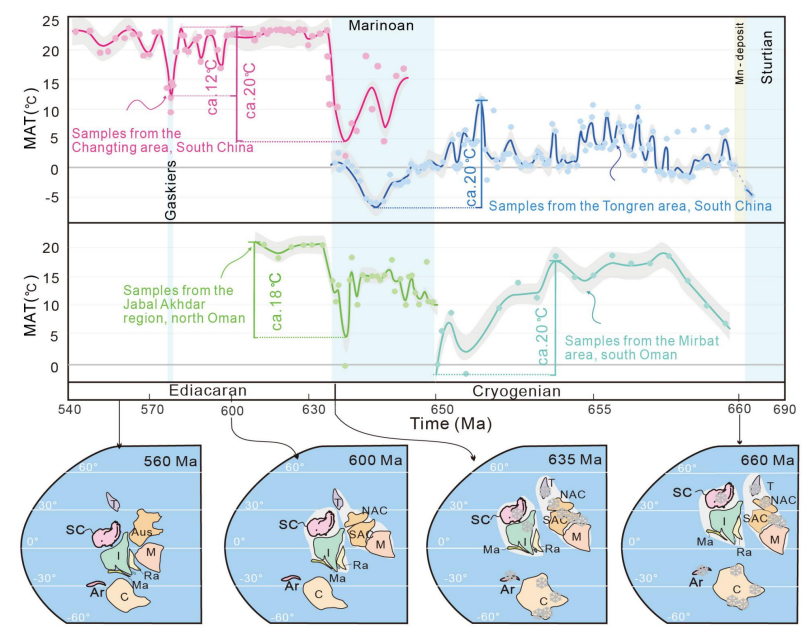

[1] Fedo et al. (1995) Geology 23 921-924. [2] Rasmussen et al. (2011) EPSL 301 521-530. [3] Yang et al. (2016) GSAB 128 739751. 